\title{
SYNTHESIS AND STRUCTURAL CHARACTERISTICS OF MAGNESIUM AND ZINC DOPED HYDROXYAPATITE WHISKERS
}

\author{
${ }^{\#} \mathrm{HONGQUAN}_{\mathrm{ZHANG}}{ }^{* * *}$, CHUNPENG ZHAO**, JIN WEN****, XIAOYAN LI**, LUWEI FU** \\ *State Key Laboratory of Silicate Materials for Architecture (Wuhan University of Technology), \\ Wuhan 430070, China \\ **School of Materials Science and Engineering, Wuhan University of Technology, \\ Wuhan 430070, Chin
}

"E-mail: zhhquan@whut.edu.cn

Submitted March 19, 2017; accepted April 18, 2017

\begin{abstract}
Keywords: $\mathrm{Mg}$ and $\mathrm{Zn}$ ions, Ions doped hydroxyapatite, Morphology of precipitates, Crystal structure
$\mathrm{Mg}$ and $\mathrm{Zn}$ doped hydroxyapatite whiskers were successfully prepared by hydrothermal homogeneous precipitation using amide additives. The morphology and structure of the products were characterized using SEM, XRD, and FTIR. It was shown that all samples prepared using $<10 \% \mathrm{~mol} \cdot l^{-1} \mathrm{Mg}$ or Zn ions were identified as HA. Further increasing their concentration gave rise to the appearance of the second phase. The $\mathrm{Mg}$ or $\mathrm{Zn}$ doped HA whiskers had a length of $60-110 \mu \mathrm{m}$ and aspect ratio of $30-50$, when the concentration of $\mathrm{Mg}$ or $\mathrm{Zn}$ ions were $<5$ mol. \%. Substitution of $\mathrm{Mg}$ or $\mathrm{Zn}$ impaired the crystallization of HA whiskers and led to changes in the morphology, lattice parameters and XRD peaks diffraction position, which demonstrated that $\mathrm{Mg}$ or/and $\mathrm{Zn}$ ions were incorporated into the unit cell of HA, rather than just absorption on the surface of the whiskers.
\end{abstract}

\section{INTRODUCTION}

Hydroxyapatite $\left(\mathrm{Ca}_{10}\left(\mathrm{PO}_{4}\right)_{6}(\mathrm{OH})_{2}, \mathrm{HA}\right)$ has good biocompatibility and bioactivity because of its mineral composition being similar to that of the hard tissues of humans, and HA based materials have been widely applied to many biomedical fields in the form of granules, blocks, and dense bodies [1, 2]. Unfortunately, their applications are limited to small and unloaded implants, powders and low-loaded porous implants due to the low rate of bone bonding ability and low reliability [1].

Reinforcement by whiskers or fibers is an effective way to improve the mechanical strength and durability of biomaterials [2]. HA whiskers reinforced bioceramics and polymer composites have shown an improved mechanical property $[3,4]$. In our previous work, long HA whiskers with high aspect ratio have been successfully developed by hydrothermal homogeneous precipitation. Their morphology and crystallinity were found to depend on the initial $\mathrm{Ca}$ concentration, $\mathrm{Ca} / \mathrm{P}$ ratio and $\mathrm{pH}[5,6]$, and the whiskers reinforced bis-GMA composition conferred a significant increase in fracture toughness and slight improvement in flexural strength $[7,8]$.

Although HA has been currently used as bone graft substitutes or coatings materials because of their excellent biocompatibility and osteoconductivity, it does not stimulate bone formation or inhibit bone resorption.
In addition, HA does not inhibit bacteria, and the infections associated with the use of biomedical materials or medical devices are a significant rising complication [9]. Prevention of implant-associated infections has been one of the main challenges in orthopaedic and dentistry surgery. Thus, the successful long-term application of prosthetic implants greatly depends on their good biocompatibility and mechanical stability as well as their antibacterial ability. The use of bioactive and antibacterial reinforcing materials not only effectively improves the direct chemical bonding strength with natural tissue, but also improves its resistance to bacterial colonisation.

$\mathrm{Zn}$ and $\mathrm{Mg}$, essential trace elements required for bone and connective tissues, have specific osteogenic effects on bone formation and selective inhibitory effect by stimulating bone cells revival, and collagen synthesis in osteoblastic cells in vitro and in vivo $[10,11] . \mathrm{Zn}^{2+}$ ions have been found to have good antibacterial potential. In addition, The chemistry of HA is complex, and a variety of substitutions can occur in the HA lattice [12]. To more accurately make HA to have the bone mineral component, both $\mathrm{Mg}$ and $\mathrm{Zn}$ doped HA powders have been successful developed from an aqueous solution. It have been found that doping $\mathrm{Mg}$ or $\mathrm{Zn}$ ions into HA crystal would impair the crystallization of HA and significantly change the lattice parameter $a$ and $c$ values of HA unit cell, and the $\mathrm{Mg}$ and $\mathrm{Zn}$ ions substitutions 
also affected the crystal morphology and their thermal behavior [13-15]. Nevertheless, no more literature reports were found about the synthesis of $\mathrm{Zn}$ or $\mathrm{Mg}$ ions doped HA whiskers. Therefore, the aim of this study was to prepare the $\mathrm{Zn}$ or $\mathrm{Mg}$ doped HA whiskers and study the effects of the $\mathrm{Zn}$ and $\mathrm{Mg}$ ions substitution on the constitution and microstructure of HA whiskers as well as the appropriate substitution degree of these ions in HA whiskers.

\section{EXPERIMENTAL}

Materials and Methods

Preparation of metal ions doped HA whiskers

Metal ions doped HA whiskers were prepared by a hydrothermal homogeneous precipitation method from aqueous solution containing calcium, phosphate, and magnesium or zinc doping ions $[5,6]$, in which acetamide $\left(\mathrm{CH}_{3} \mathrm{CONH}_{2}\right)$ (all above from AnalaR, Sinopharm Chemical Reagent Co., Ltd., Shanghai, China) was used as additive, according to the following equations:

$$
\begin{aligned}
& (10-x) \mathrm{Ca}^{2+}+x \mathrm{M}^{2+}+6 \mathrm{PO}_{4}{ }^{3-}+2 \mathrm{H}_{2} \mathrm{O} \rightarrow \\
& \rightarrow \mathrm{Ca}_{10-x} \mathrm{M}_{x}\left(\mathrm{PO}_{4}\right)_{6}(\mathrm{OH})_{2}+2 \mathrm{H}^{+} \quad(\mathrm{M}=\mathrm{Zn} \text { or } \mathrm{Mg}) \\
& \mathrm{CH}_{3} \mathrm{CONH}_{2}+\mathrm{H}_{2} \mathrm{O} \rightarrow \mathrm{CH}_{3} \mathrm{COOH}+\mathrm{NH}_{3}
\end{aligned}
$$

The aqueous solutions containing 2 - 40 mol. $\% \mathrm{Mg}$ or $\mathrm{Zn}$ ions were prepared by dissolving appropriate amounts of $\mathrm{Ca}\left(\mathrm{NO}_{3}\right)_{2} \cdot 4 \mathrm{H}_{2} \mathrm{O}, \mathrm{Mg}\left(\mathrm{NO}_{3}\right)_{2} \cdot 6 \mathrm{H}_{2} \mathrm{O}, \mathrm{Zn}\left(\mathrm{NO}_{3}\right)_{2}$. $\cdot 6 \mathrm{H}_{2} \mathrm{O}, \mathrm{NH}_{4} \mathrm{H}_{2} \mathrm{PO}_{4}$ and $\mathrm{CH}_{3} \mathrm{CONH}_{2}$ in deionized water, keeping the $(\mathrm{Ca}+\mathrm{M}) / \mathrm{P}$ molar ratio of 1.67 . The initial $\mathrm{pH}$ value was adjusted to 3.00 by adding $1: 1$ ammonium hydroxide or $1 \mathrm{~mol} \cdot \mathrm{l}^{-1} \mathrm{HNO}_{3}$ solutions. The mixture was then placed into a high-temperature reactor and hydrothermally treated at $170 \sim 190^{\circ} \mathrm{C}$ for $10 \mathrm{~h}$. After processing, the precipitates obtained were filtered through paper (Qualitative, Advantec, Toyo Roshi Kaisha, Japan) and washed using deionized water. Finally they were dried in an oven at $80^{\circ} \mathrm{C}$ for 3-4 h for use

\section{Characterization of metal ions doped HA whiskers}

The phase composition of the products were characterized using X-ray powder diffraction (XRD) (D/MAX-RB, RIGAKU, Japan ) in a range of $2 \theta=$ $=10 \sim 70^{\circ}$ with $\mathrm{Cu} \mathrm{K \alpha}$ radiation at $0.02^{\circ}$ step and Fourier-transform infrared spectroscopy (FTIR) (Nicolet iS10, Thermo Nicolet, USA) in a range of 4000 $\sim 400 \mathrm{~cm}^{-1}$. The lattice parameters were determined by Rietveld refinements from the well determined and intense reflections using MDI Jade 5.0 software. Their morphology and microstructure were observed using a scanning electron microscopy (SEM) (JSM-5610LV, JEOL, Japan) with an accelerating voltage of $5 \sim 10 \mathrm{kV}$ at a working distance of $10 \sim 15 \mathrm{~mm}$. The $\mathrm{pH}$ of the solu- tion before and after the synthesis was measured with a combination electrode (PHS-3C, Shanghai Precision \& Scientific Instrument Co., Ltd., Shanghai) at room temperature $\left(25 \pm 2{ }^{\circ} \mathrm{C}\right)$.

\section{RESULT AND DISCUSSION}

Phase composition

Figures 1 and 2 show the XRD pattern of samples prepared with various concentrations of $\mathrm{Mg}$ or $\mathrm{Zn}$ doping ions. For those of $\mathrm{Mg}$ or $\mathrm{Zn}$ doping ratio being $<10 \%$, all XRD peaks matched well with the standard pattern of HA (PDF9-0432), indicating that the incorporation of $\mathrm{Mg}$ or $\mathrm{Zn}$ did not affect the diffraction pattern of HA crystals. To obtain a product with single phase composition, $\mathrm{Mg}$ or $\mathrm{Zn}$ doping concentration in the initial solution should be $<10 \mathrm{~mol}$. \%. Further increasing the doping proportion, undesirable calcium magnesium hydrogen phosphate $\left(\mathrm{Ca}_{19.68} \mathrm{Mg}_{0.12} \mathrm{H}_{1.8}\left(\mathrm{PO}_{4}\right)_{13.80}\right.$, PDF792186) or Scholzite $\left(\mathrm{CaZn}_{2}\left(\mathrm{PO}_{4}\right)_{2} \cdot 2 \mathrm{H}_{2} \mathrm{O}, \mathrm{PDF} 27-0095\right)$ would accompany $\mathrm{HA}$ in the products. When $\mathrm{Mg}$ doping concentration was $>15 \mathrm{~mol}$. \% or Zn doping concentration was $>20 \mathrm{~mol} . \%$, the phase composition of the precipitate was almost composed of $\mathrm{Ca}_{19.68} \mathrm{Mg}_{0.12} \mathrm{H}_{1.8}\left(\mathrm{PO}_{4}\right)_{13.80}$, or Scholzite. The formation of Scholzite phase from a staring solution containing high $\mathrm{Zn}^{2+}$ concentration was also reported by Miyaji during the preparation of Zn-substituted HA [16].

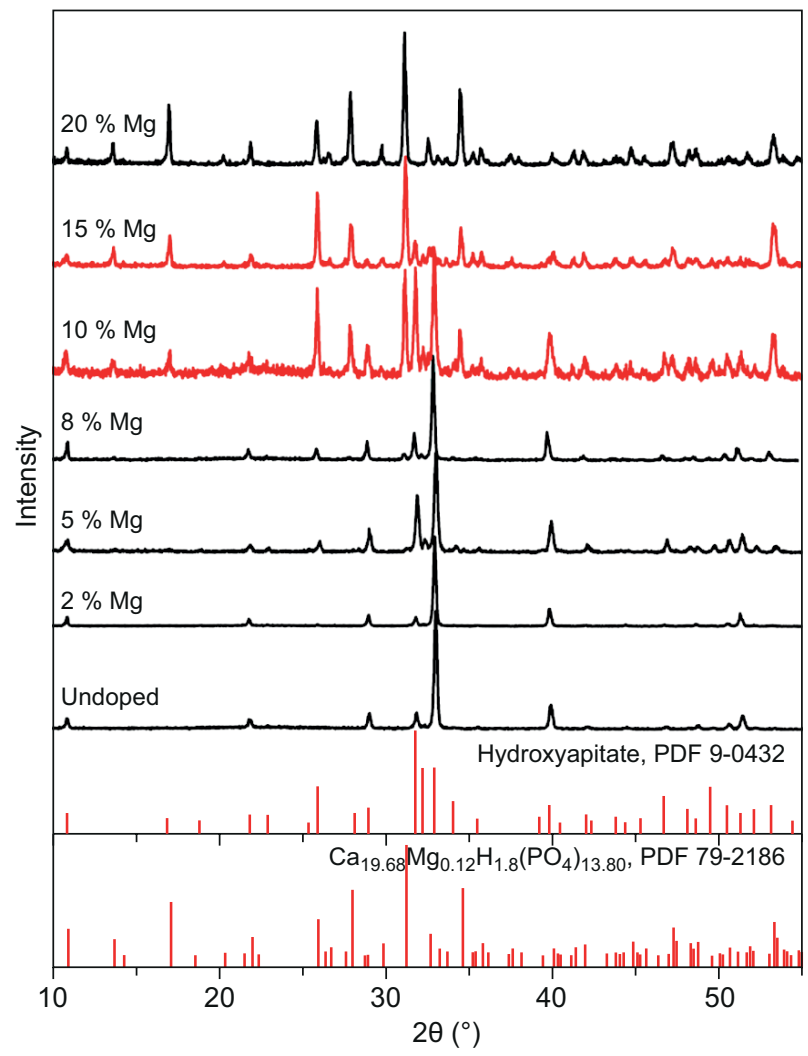

Figure 1. XRD pattern of the samples doped with Mg ions. 


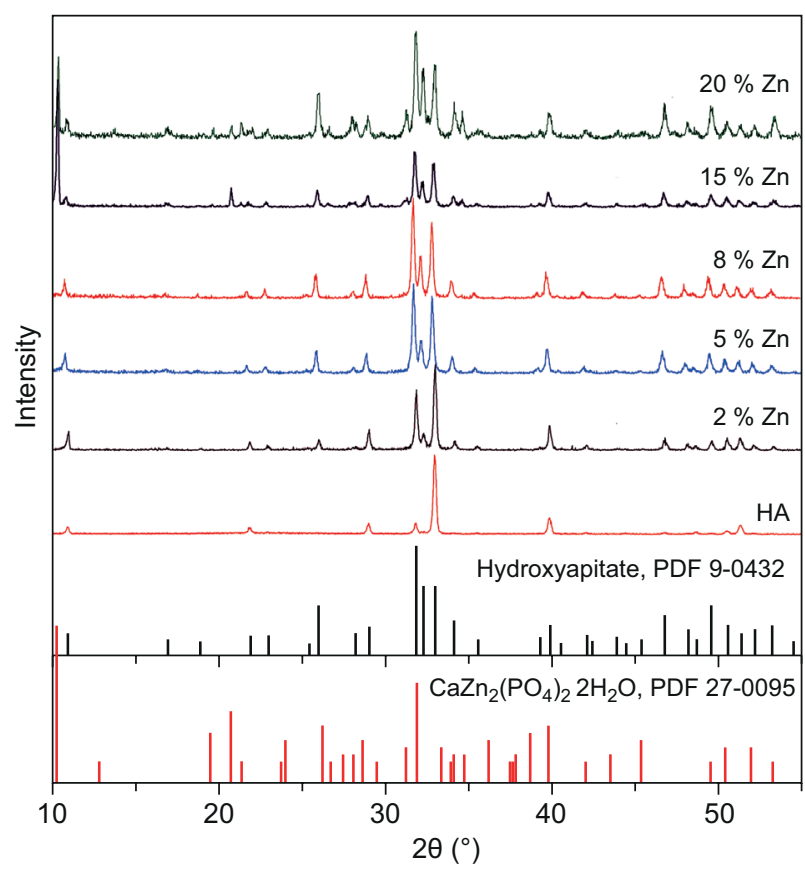

Figure 2. XRD pattern of the samples doped with $\mathrm{Zn}$ ions.

Figure 3 shows the FTIR spectra of the products prepared using various initial metal ions concentrations. Characteristic bands at about 1092, 1034, 605 and 565 $\mathrm{cm}^{-1}$ for phosphate and at about 3570 and $638 \mathrm{~cm}^{-1}$ for hydroxyl were similar in each, despite a slight calcium deficiency. Increasing the initial metal ions concentration did not affect the position of those characteristic bands. However, incorporation of $\mathrm{Mg}$ or $\mathrm{Zn}$ affected the intensity of the $\mathrm{OH}^{-}$liberation mode. The corresponding band at $638 \mathrm{~cm}^{-1}$ was obvious for the $\mathrm{Zn}$ doped samples, being coincident with $\mathrm{Li}$ [17]. Whereas, for the Mg doped sample, such band disappeared for the sample doped with $15 \mathrm{~mol} \% \mathrm{Mg}$, which agreed with the results of the XRD analysis. In addition, the appearance of symmetrical stretching vibration bands at about $871 \mathrm{~cm}^{-1}$, assigned to $\mathrm{HPO}_{4}^{2-}$, indicated that the samples had slight calcium deficiency due to the ion substitution.

\section{Lattice parameters}

Changes of the lattice parameters and crystallinity (Xc) of the HA doped with various amounts of $\mathrm{Mg}$ or $\mathrm{Zn}$ ions were given in Table 1 . The degree of crystallinity was calculated by [18]:

$$
X c=1-\mathrm{V}_{(112 / 300)} / \mathrm{I}_{300}
$$

where $\mathrm{V}_{(112 / 300)}$ is the intensity of the hollow between the (112) and (300) diffraction peaks and $\mathrm{I}_{300}$ is the intensity of the (300) diffraction peak in the corresponding XRD pattern.

It has been proved that the substitution of $\mathrm{Ca}, \mathrm{PO}_{4}$ or $\mathrm{OH}$ groups by other ions may result in change in various structural properties [12]. Substitution of $\mathrm{Mg}$ in HA crystals obviously reduced the crystallinity of HA whiskers and both the $a$ and $c$ values of HA unit cell, especially for that of HA crystals doped with $\geq 8 \% \mathrm{Mg}$,

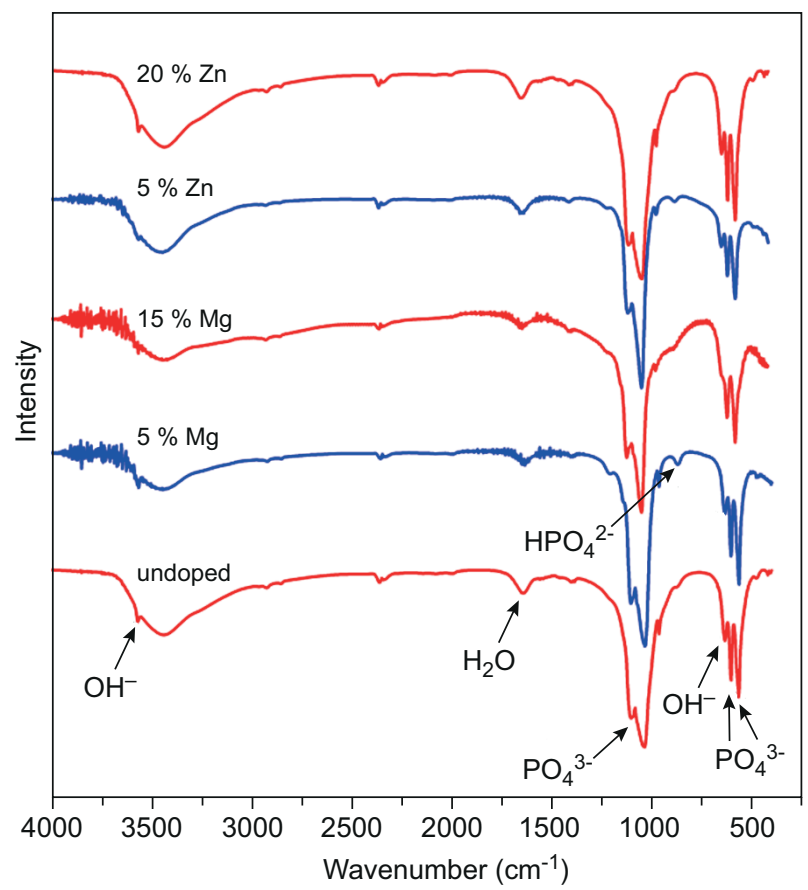

Figure 3. FTIR spectra of specimens prepared using various initial metal ions concentration.

Table 1. Lattice parameters of the products doped with single metal ions.

\begin{tabular}{lccccc}
\hline $\begin{array}{l}\text { Initial metal } \\
\text { ions ratio (mol. \%) }\end{array}$ & $a$ & $\Delta a$ & $c$ & \multicolumn{2}{c}{ Crystallinity $(\%)$} \\
\cline { 2 - 4 } Undoped & $9.4215 \pm 0.0022$ & & $6.8877 \pm 0.0029$ & \multicolumn{2}{c}{ Xc } \\
$2 \% \mathrm{Mg}$ & $9.4188 \pm 0.0008$ & -0.0027 & $6.8857 \pm 0.0105$ & -0.0020 & 98.84 \\
$5 \% \mathrm{Mg}$ & $9.4161 \pm 0.0007$ & -0.0054 & $6.8670 \pm 0.0063$ & -0.0207 & 97.55 \\
$8 \% \mathrm{Mg}$ & $9.4027 \pm 0.0022$ & -0.0188 & $6.8456 \pm 0.0031$ & -0.0421 & 93.58 \\
$2 \% \mathrm{Zn}$ & $9.4166 \pm 0.0015$ & -0.0049 & $6.8637 \pm 0.0014$ & -0.0240 & 95.81 \\
$5 \% \mathrm{Zn}$ & $9.4381 \pm 0.0005$ & 0.0164 & $6.8800 \pm 0.0034$ & -0.0077 & 93.55 \\
$8 \% \mathrm{Zn}$ & $9.4423 \pm 0.0017$ & 0.0208 & $6.8830 \pm 0.0014$ & -0.0047 & 92.48 \\
\hline
\end{tabular}


which was coincident with the previous reports $[19,20]$. However, the changes in the lattice parameters for $\mathrm{Zn}$ doped HA did not show any regularity, the $a$ value increased when the doping concentration was $>5 \%$, but the $c$ value nearly remained a constant value, which was consistent with the finding of Miyaji [16], who reported that the lattice parameter $a$ decreased up to $5 \mathrm{~mol} . \% \mathrm{Zn}$, and started to increase over $5 \mathrm{~mol}$. \% Zn. This increase in the lattice parameters was ascribed by an increasing amount of lattice $\mathrm{H}_{2} \mathrm{O}$. Such a phenomenon also could be confirmed by the FTIR spectra, as shown in Figure 3 . The $\mathrm{OH}^{-}$characteristic bands at $3570 \mathrm{~cm}^{-1}$ were visible for all the Zn substituted HA samples. However, such result was also different from the report of $\mathrm{Li}$ [17], the differences might be caused due to the low synthesis $\mathrm{pH}$ value. To deep insight into the reason, further research would be needed.

Figure 4 shows the XRD pattern of the samples doped with $5 \mathrm{~mol}$. \% $\mathrm{Zn}$ and $\mathrm{Mg}$ at various ratios. The XRD diffraction peak shifted obviously to a lower diffraction angles with the increase of the concentration of Zinc ions, when compared with that of the sample doped with $5 \% \mathrm{Mg}$. Both $a$ and $c$ significantly increased with the proportion of $\mathrm{Zn}$ (Figure 5), and the regression line showed reasonably good fits for both $a$ and $c$ value. The relationship of the difference in $a$ or $c$ value ( $\Delta a$ or $\Delta c$ ) between the $\mathrm{Mg}$ and $\mathrm{Zn}$ doped samples and the $5 \%$ $\mathrm{Mg}$ doped HA is given by the Equations 2 and 3, giving a correlation coefficient of 0.98 and 0.99 , respectively:

$$
\begin{aligned}
\Delta a & =0.0236 x+0.0001 \\
\Delta c & =0.0128 x+0.0005
\end{aligned}
$$

where $x$ equals $[\mathrm{Zn}] /([\mathrm{Mg}]+[\mathrm{Zn}])$. The result revealed that doping $\mathrm{Zn}$ ions into HA crystal would increase both the lattice parameter $a$ and $c$ values of HA unit cell in the mixed doping system, which might be related to the different radius between $\mathrm{Mg}$ and $\mathrm{Zn}$ ions.

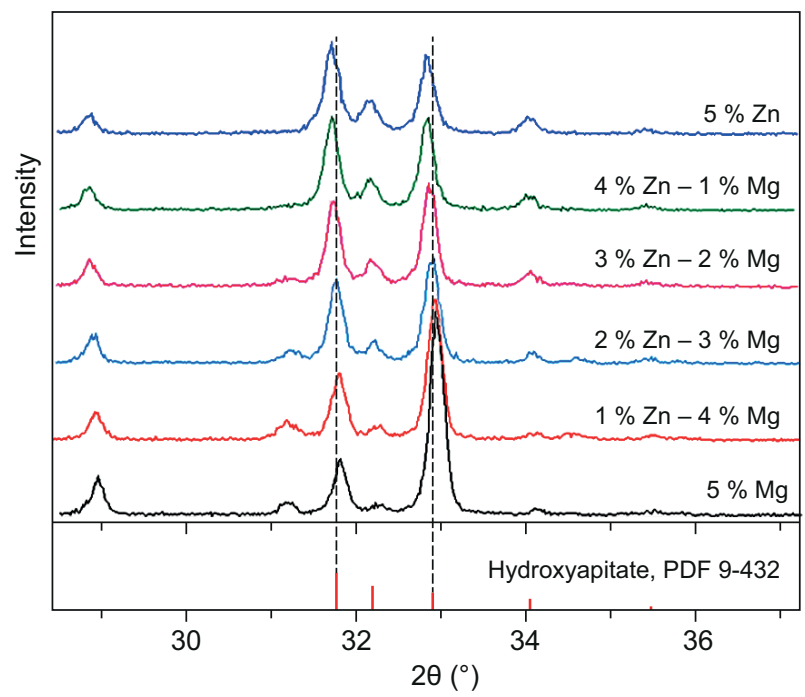

Figure 4. XRD pattern of the samples doped with $5 \% \mathrm{Mg}$ and $\mathrm{Zn}$ ions at various ratios.
Ionic substitutions in the crystallographic sites of HA lattice generally cause changes in cell parameters, depending on the sizes of doping ions. $\mathrm{Zn}$ and $\mathrm{Mg}$ have a substantially smaller ionic radius of $0.72 \AA$ and $0.66 \AA$, respectively, compared to $\mathrm{Ca}(1.00 \AA)$. Thus, $\mathrm{Mg}$ or $\mathrm{Zn}$ ions doped HA would lead XRD peak to shift to a high diffraction angle according to the Bragg equation in crystal diffraction. For $\mathrm{Zn}$ and $\mathrm{Mg}$ mixed ions doped $\mathrm{HA}$, increasing the proportion of $\mathrm{Zn}$ ions would cause the XRD peak shift to a lower diffraction angles and led to a increase in the cell parameters $a$ and $c$ slightly, when compared with the single $\mathrm{Mg}$ ions doped HA. Considering the results showed in Table 1 and Figures 4-5, the replacement of $\mathrm{Zn}^{2+}$ at the $\mathrm{Ca}$ site seems energetically more favorable at the $\mathrm{Ca}(1)$ sites. Whereas, for Mg ions doped HA, both $a$ and $c$ were smaller than those of the pure $\mathrm{HA}$, the replacement of $\mathrm{Mg}^{2+}$ seems more favorable at the both $\mathrm{Ca}(1)$ and $\mathrm{Ca}(2)$ sites, but more examinations should be conducted in the later research. The change of the lattice parameters of $\mathrm{Zn}$ or/ and $\mathrm{Mg}$-HA clearly demonstrated that $\mathrm{Mg}$ or $\mathrm{Zn}$ ions were structurally incorporated into the apatite crystals, they were not just absorbed on the surface of crystal.

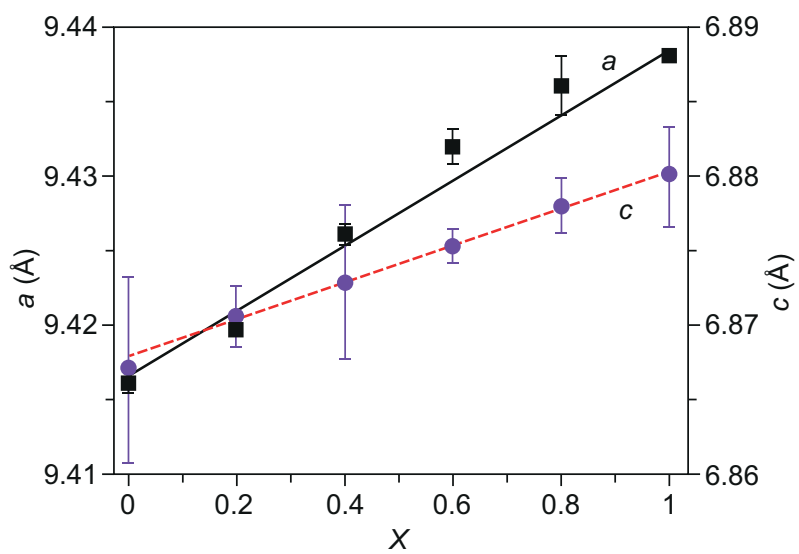

Figure 5. Changes of lattice parameters of the samples doped with $5 \mathrm{~mol} . \% \mathrm{Mg}$ and $\mathrm{Zn}$ mixed ions with the proportion of $\mathrm{Zn}$.

\section{The morphology}

Figure 6 shows the SEM micrographs of the precipitates. The $\mathrm{Mg}$ or $\mathrm{Zn}$ ions doped HA exhibited a whisker-like morphology and had a length of $60-110 \mu \mathrm{m}$ and aspect ratio $30-50$ when the doping proportion of $\mathrm{Mg}$ or $\mathrm{Zn}$ ions were less than $5 \mathrm{~mol}$ \%. With the increase of $\mathrm{Mg}$ or $\mathrm{Zn}$ concentration in the initial synthesis solution, both the length and aspect ratio were impaired. For the proportion of $\mathrm{Mg}$ ions of $>15 \%$, few second phases appeared in the products, they were identified as $\mathrm{Ca}_{19.68} \mathrm{Mg}_{0}{ }_{12} \mathrm{H}_{1.8}\left(\mathrm{PO}_{4}\right)_{13.80}$, showing irregular morphology (Figures 4a-c). Whereas, for the precipitates of $\mathrm{Zn}$ doped $\mathrm{HA}, \mathrm{CaZn}_{2}\left(\mathrm{PO}_{4}\right)_{2} \cdot 2 \mathrm{H}_{2} \mathrm{O}$ was found to be one of the main phase when the concentration of $\mathrm{Zn}$ ions was $>15 \%$, showing regular dodecahedral morphology. The morphology of metal ions doped HA whiskers was 


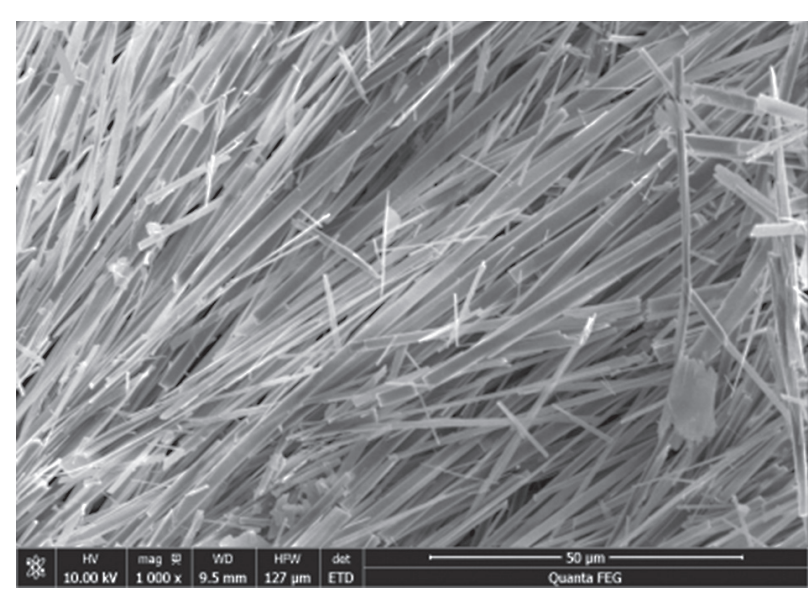

a) $5 \% \mathrm{Mg}$

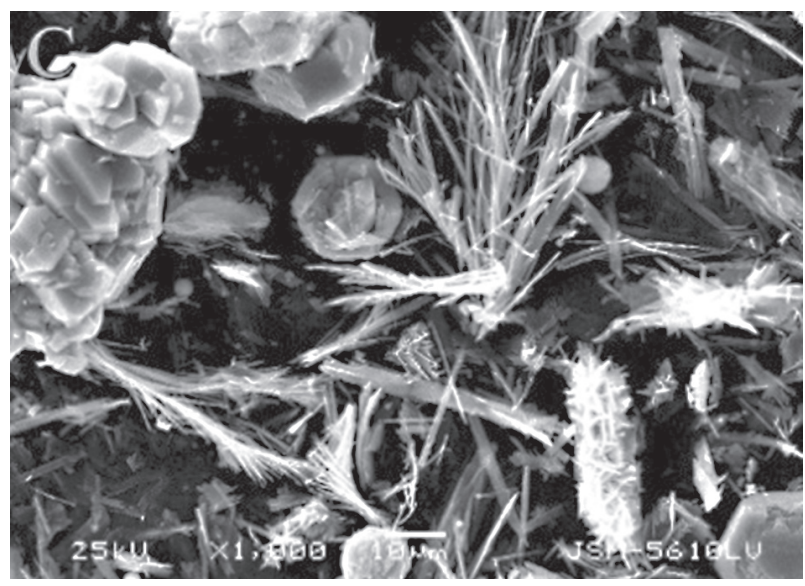

c) $15 \% \mathrm{Mg}$

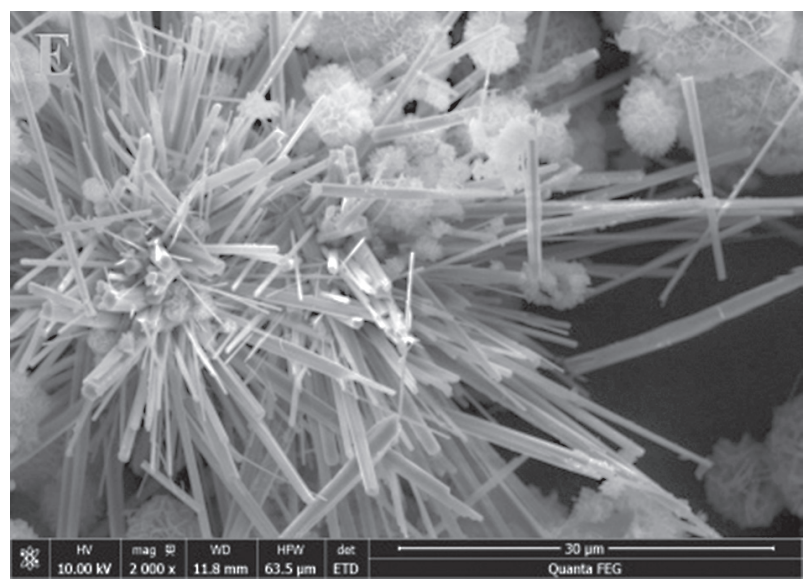

e) $8 \% \mathrm{Zn}$

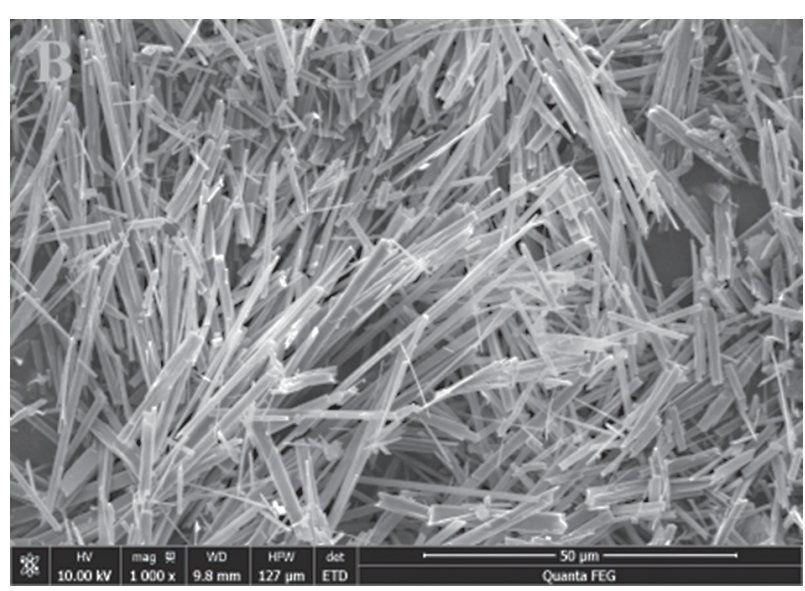

b) $8 \% \mathrm{Mg}$

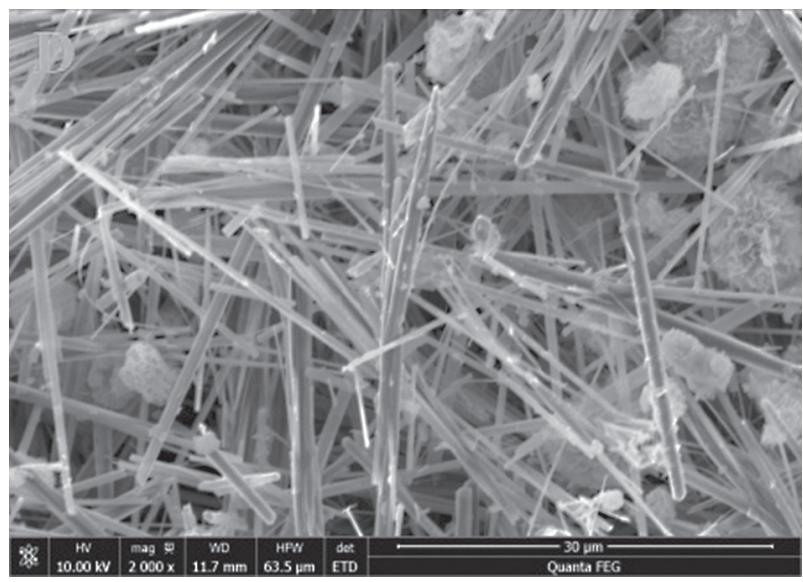

d) $5 \% \mathrm{Zn}$

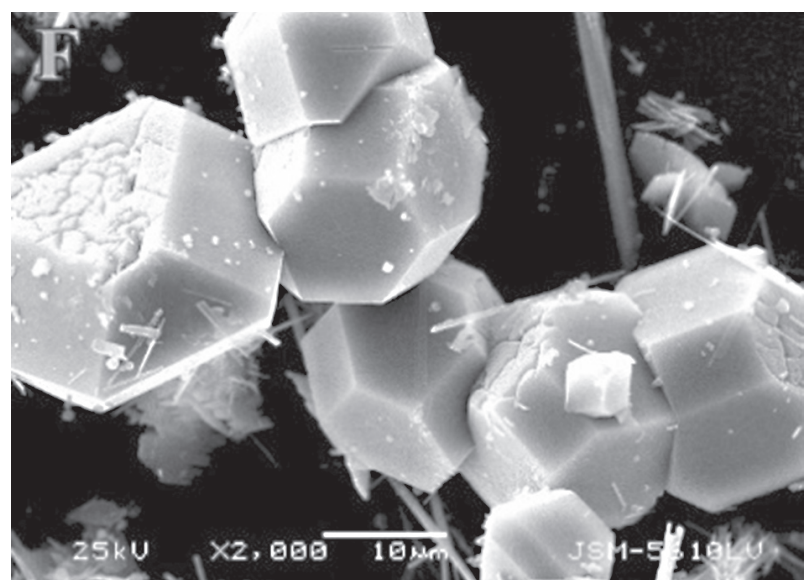

f) $15 \% \mathrm{Zn}$

Figure 6. SEM photographs of the metal ions doped HA; a) $5 \% \mathrm{Mg}$, b) $8 \% \mathrm{Mg}$, c) $15 \% \mathrm{Mg}$, d) $5 \% \mathrm{Zn}$, e) $8 \% \mathrm{Zn}$, f) $15 \% \mathrm{Zn}$.

obviously affected by both the species of doping ions and their content in the synthesis solution. Low doping ions concentration favored the precipitation of long HA whiskers with high aspect ratio.

\section{CONCLUSION}

$\mathrm{Mg}$ or $\mathrm{Zn}$ ions doped HA whiskers have been successfully prepared using amide additives from a solution containing calcium, phosphate and doped ions by hydrothermal homogeneous precipitation at $170-190^{\circ} \mathrm{C}$ for 10 - $12 \mathrm{~h}$. The Mg or $\mathrm{Zn}$ doped HA whiskers had a length of $60-110 \mu \mathrm{m}$ and aspect ratio of $30-50$, when starting concentration of $\mathrm{Mg}$ or $\mathrm{Zn}$ ions were less than 5 mol. \%. Their length would be impaired by increasing the initial concentration of $\mathrm{Mg}$ and $\mathrm{Zn}$ ions. Further increasing the concentration of $\mathrm{Zn}$ or $\mathrm{Mg}$ ion more than $10 \mathrm{~mol} . \%$ gave rise to the appearance of the second 
phase $\mathrm{CaZn}_{2}\left(\mathrm{PO}_{4}\right)_{2} \cdot 2 \mathrm{H}_{2} \mathrm{O}$ or $\mathrm{Ca}_{19.68} \mathrm{Mg}_{0} \cdot{ }_{12} \mathrm{H}_{1.8}\left(\mathrm{PO}_{4}\right)_{13.80}$. Therefore, the appropriate starting concentration of these ions in HA whiskers should be less than $10 \mathrm{~mol} . \%$.

\section{Acknowledgements}

This project was supported by the National Natural Science Foundation of China (Grant No. 51372182), the Fundamental Research Funds for the Central Universities of China (Grant No. 2011-IV-133).

\section{REFERENCES}

1. Aoki H. (1991): Science and medical applications of hydroxyapatite. Takayama Press.

2. Dorner-Reisel A., Muller E., Tomandl G. (2004): Short fiber reinforced hydroxyapatite based bioceramics. Advanced engineering materials, 6(7), 572-577. doi: 10.1002/ adem. 200400401

3. Roeder R. K., Sproul M. M., Turner C. H. (2003): Hydroxyapatite whiskers provide improved mechanical properties in reinforced polymer composites. Journal of Biomedical Materials Research Part A, 67(3), 801-812. doi: 10.1002/ jbm.a.10140

4. Suchanek W., Yashima M., Kakihan M., Yoshimura M. (1997): Hydroxyapatite/hydroxyapatite-whiskers composites without sintering additives: Mechanical properties and microstructural evolution. Journal of the American Ceramic Society, 80(11), 2805-2813. doi: 10.1111/j.11512916.1997.tb03197.x

5. Zhang H., Darvell B.W. (2011): Morphology and structural characteristics of hydroxyapatite whiskers: Effect of the initial ca concentration, $\mathrm{Ca} / \mathrm{P}$ ratio and $\mathrm{pH}$. Acta Biomaterialia, 7(7), 2960-2968. doi:10.1016/j.actbio.2011. 03.020

6. Zhang H., Darvell B.W. (2010): Synthesis and characterization of hydroxyapatite whiskers by hydrothermal homogeneous precipitation using acetamide. Acta Biomaterialia, 6(8), 3216-3222. doi:10.1016/j.actbio.2010.02.011

7. Zhang H., Darvell B.W. (2012): Mechanical properties of hydroxyapatite whisker-reinforced bis-gma-based resin composites. Dental materials, 28(8),824-30. doi:10.1016/j. dental.2012.04.030

8. Zhang H., Darvell B.W. (2012): Failure and behavior in water of hydroxyapatite whisker-reinforced bis-GMAbased resin composites. Journal of the mechanical behavior of biomedical materials, 10, 39-47. doi:10.1016/j. jmbbm.2012.02.021

9. Thian E.S, Konishi T., Kawanobe Y., Lim P. N., Choong C., Ho B., Aizawa M. (2013): Zinc-substituted hydroxyapatite:
A biomaterial with enhanced bioactivity and antibacterial properties. Journal of Materials Science: Materials in Medicine, 24(2), 437-445. doi: 10.1007/s10856-0124817-x

10. Ilich J. Z., Kerstetter J.E. ( 2000): Nutrition in bone health revisited: A story beyond calcium. Journal of the American College of Nutritionr, 19(6),715-37. doi:10.1080/07315724 .2000 .10718070

11. Landi E., Logroscino G., Proietti L., Tampieri A., Sandri M., Sprio S. (2008): Biomimetic Mg-substituted hydroxyapatite: From synthesis to in vivo behaviour. Journal of Materials Science: Materials in Medicine, 19(1), 239-47. doi: 10.1007/s10856-006-0032-y

12. Shepherd J. H., Shepherd D. V., Best S. M. (2012): Substituted hydroxyapatites for bone repair. Journal of Materials Science: Materials in Medicine, 23(10), 2335-2347. doi: 10.1007/s10856-012-4598-2

13. Fadeev I. V., Shvorneva L. I., Barinov S. M., Orlovskii V. P. (2003):Synthesis and structure of magnesium-substituted hydroxyapatite. Inorganic Materials, 39(9), 947-950. doi: 10.1023/A:1025509305805

14. Matsunaga K. (2008): First-principles study of substitutional magnesium and zinc in hydroxyapatite and octacalcium phosphate. Journal of Chemical Physics, 128(24), 245101. doi: 10.1063/1.2940337

15. Bigi A., Falini G., Foresti E., Ripamonti A., Gazzano M., Roveri N. (1993): Magnesium influence on hydroxyapatite crystallization. Journal of Inorganic Biochemistry, 49, 69-78. doi:10.1016/0162-0134(93)80049-F

16. Miyaji F., Kono Y., Suyama Y. (2005): Formation and structure of zinc-substituted calcium hydroxyapatite. Materials Research Bulletin, 40(2),209-220. doi: 10.1016/j. materresbull.2004.10.020

17. Li M., Xiao X., Liu R., Huang L. (2008): Structural characterization of zinc-substituted hydroxyapatite prepared by hydrothermal method. Journal of Materials Science: Materials in Medicine, 19(2): 797-803. doi:10.1007/ s10856-007-3213-4

18. Nilen R.W., Richter P.W.. (2008): The thermal stability of hydroxyapatite in biphasic calcium phosphate ceramics. Journal of Materials Science: Materials in Medicine, 19(4), 1693-702. doi:: 10.1007/s10856-007-3252-x

19. Zhang H., Zhang M., Fu L., Cheng Y. N. (2013): Synthesis and structural characterization of zinc and magnesium doped hydroxyapatite. Key Engineering Materials, 531-532, 250-253. doi:10.4028/www.scientific.net/KEM. $531-532.250$

20. Cacciotti I., Bianco A., Lombardi M., Montanaro L. (2009): Mg-substituted hydroxyapatite nanopowders: Synthesis, thermal stability and sintering behaviour. Journal of the European Ceramic Society, 29(14), 2969-2978. doi:10.1016/ j.jeurceramsoc.2009.04.038 